\title{
Robert Matijašić
}

\section{Predgovor}

straživanja u okviru znanstvenoga projekta »Naseljenost i gospodarstvo Istre od kraja prapovijesti do Bizanta« (303-3030822-0932) bila su od 2006. godine usmjerena k fenomenima i prostoru koji su definirani u naslovu, a rad istraživača i suradnika na koncu je predstavljen u trima knjigama, u dvadesetak tekstova koji su klasificirani kao »poglavlje u knjizi« te u dvadesetak tekstova u znanstvenim časopisima. Niz dosad neobjavljenih tekstova odlučili smo objaviti u obliku zbornika koji je posvećen projektu, a »udomljeni« su u časopisu »Tabula« razumijevanjem uredništva, kojemu i ovdje zahvaljujemo.

Naseljavanje i gospodarstvo nekoga područja u antici (a to jest razdoblje od kraja prapovijesti do početka bizantske vlasti u Istri) valja promatrati kao jedinstveni i cjeloviti fenomen, često zajedno s drugim pojavnostima. No povijesno-arheološka metodologija istraživanja obično usmjerava znanstvenika prema užim segmentima teme: očevidno je da nisu još sazrjeli uvjeti za pisanje sinteze o povijesti naseljavanja i gospodarstva Istre u prapovijesti i antici. Tekstovi zastupljeni u ovom zborniku projekta obuhvaćaju teme iz prapovijesti i antike, do kasne antike i njezina susreta s početkom ranoga srednjeg vijeka.

Naseljena od paleolitika (Šandalja) Istra je kroz ljudsku povijest uvijek bila stanište ljudskih zajednica. Poslije špiljskih naselja u paleolitiku i mezolitiku (Pupićina peć), neolitski stanovnici izlaze na otvoreni prostor, gradeći nastambe od prirodnih materijala, a ubrzo se, s pojavom metala, uspinju na gradine, koje su im pružale bolju zaštitu od opasnosti. Gradine (kašteljeri, tal. castellieri) i danas su najuočljiviji oblik naseljavanja u istarskome krajoliku, pogotovo na nekim dijelovima poluotoka u kojima brežuljasti kraški teren pruža dobre mogućnosti fortifikacije.

Na željeznodobnim gradinama (prvo tisućljeće pr. Kr.) živjeli su Histri, prvi etnički definirani narod u Istri (koji su, uostalom, Istri i dali današnje ime). I Nezakcij je bio takva gradina, prema Titu Liviju posljednje uporište u ratu kojim je rimska vojska osvojila i svojoj vlasti podredila Istru. S dolaskom Rimljana struktura se naseljavanja mijenja: Histri napuštaju gradine, a rimski kolonisti osnivaju gradove ustrojene po klasičnim paradigmama. No oko gradova niču poljoprivredna imanja kojima su središta bile skupine građevina stambenoga i gospodarskoga karaktera (villae rusticae). Taj je model (gradsko naselje + seoska imanja) odredio naseobinski krajolik Istre za sljedeća stoljeća, a iz njega je proizišao i kasniji, srednjovjekovni i današnji istarski krajolik. Gradovi su mahom bez prekida naseljeni od antike do danas, na nekim su gradinama nastali ustvrđeni srednjovjekovni istarski gradići, a od rustičkih vila su se razvile stancije (današnja naselja morfološki slična rimskim gospodarskim vilama) i brojna današnja naselja, sela i gradići. Religijski je krajolik također vrlo izražen, pa i on svjedoči o nekadašnjim naseljima čije su crkve na osami u poljoprivrednom krajoliku jedini danas vidljivi trag. 
Proučavanje naseljavanja stoga je neraskidivo povezano s gospodarstvom, jer je čovjek, da bi preživio, morao proizvoditi hranu i sve potrepštine te razmjenjivati svoje proizvode na bližim i daljim tržištima. Ono je povezano i sa svim drugim oblicima manifestacija ljudske opstojnosti (vjera, umjetnost, kultura) te je sastavnim dijelom povijesnih istraživanja nekoga teritorija. Istra je za to vrlo pogodno područje jer se radi o dobro definiranoj zemljopisnoj cjelini koja je uvijek u prošlosti bila pod utjecajem susjednih zemalja, a istovremeno i prostor na kojemu se pod tim utjecajima stvarala i održavala kulturna i kulturološka samosvojnost.

Zbornik ovih radova, kako je već naglašeno, nije sinteza saznanja, već pruža niz novih elemenata za jednu buduću sintezu povijesti Istre, za koju se nadamo da nije više daleko. 